Asia Proceedings of Social Sciences

(APSS)

www.readersinsight.net/APSS

\title{
VISION \& MISSION, ORGANIZATIONAL PERFORMANCE AND CORPORATE IMAGE ON CONSUMER GOODS COMPANY Friska Sipayung*
}

Faculty of Economics and Business Universitas Sumatera Utara, Medan Indonesia

\section{Liasta Ginting}

Faculty of Economics and Business Universitas Sumatera Utara, Medan Indonesia

\section{Magdalena Linda Leonita Sibarani}

Faculty of Economics and Business Universitas Sumatera Utara, Medan Indonesia

*Corrosponding author's Email: friska@usu.ac.id

Author's Biography:

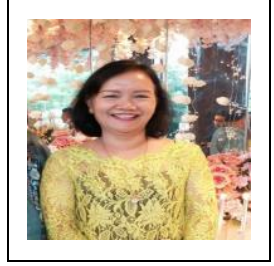

Bulan, Medan, Indon

Name

: Friska Sipayung

Place \& Date of Birth : Sidikalang, January 17,1962

Job

: Lecturer at the Faculty of Economics and Business, Universitas Sumatera Utara, Medan, Indonesia

Subjects Taught

: Strategic Management

Address

: Jl Mesjid Syuhada Gang Sepadan No. 7, Padang

Peer-review under responsibility of $3^{\text {rd }}$ Asia International Multidisciplanry Conference 2019 editorial board (http://www.utm.my/asia/our-team/)

(C) 2019 Published by Readers Insight Publisher, lat 306 Savoy Residencia, Block 3 F11/1,44000 Islamabad. Pakistan, 


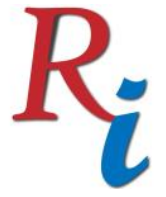

\section{Asia Proceedings of Social Sciences \\ (APSS) \\ www.readersinsight.net/APSS}

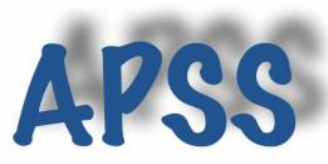

\section{Rese a r ch H i g h I igh t s}

This study will analyze the relationship between mission statements and performance and with the Corporate Image. Some research (Bart, C.K, 2007; Campbell and Yeung, 2007) illustrate how vision and mission statements can be used to build common sense and share goals and also function as tools through which employee focus is formed. While other studies show that vision and mission statements have a positive impact on profitability and can increase equity, they also report that nearly 40 percent of employees do not know or understand their company's vision and mission (Bart and Tabone, 2007). One criticism of the vision and mission is that too much is common and is not followed up. They also state that often vision statements create confusion (William and Kofi, 2012). This study will analyze the relationship between mission statements and performance and with the Corporate Image. Some research (Bart, C.K, 2007; Campbell and Yeung, 2007) illustrate how vision and mission statements can be used to build common sense and share goals and also function as tools through which employee focus is formed. While other studies show that vision and mission statements have a positive impact on profitability and can increase equity, they also report that nearly 40 percent of employees do not know or understand their company's vision and mission (Bart and Tabone, 2007). One criticism of the vision and mission is that too much is common and is not followed up. They also state that often vision statements create confusion (William and Kofi, 2012). But, this research results show that consumer goods company have a weighted value of $\geq 4$ (four). That there is a strong enough positive correlation between vision mission and organizational performance. There is a fairly strong correlation between vision mission and corporate image. There is a strong positive correlation between organizational performance and corporate image

\section{Graphical Abstract}

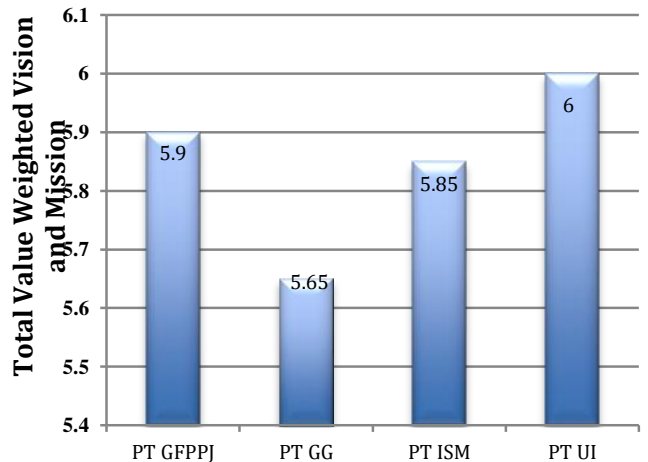

Fig. 1. The position/rank of each company based on criterion to achievement of a good vision and mission

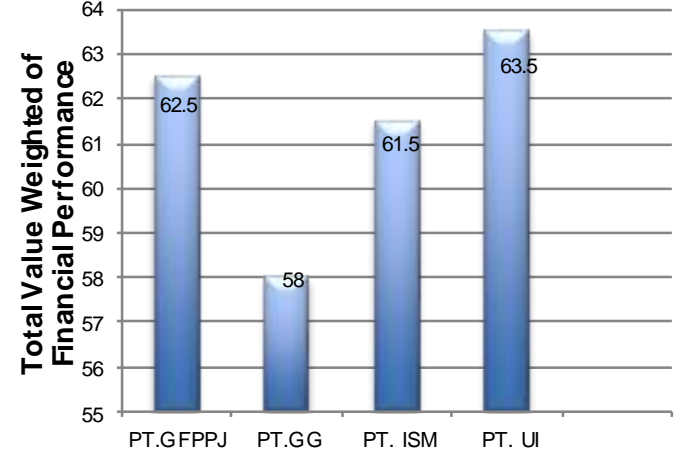

Fig. 2. Consumer goods company position Based on Financial Performance

\section{Research Objectives}

The purpose of this study is to find out and analyze:

1 . Why is consumer goods company can get IMAC 2018

2. Is there something to do with vision and mission statement

3. The relationship between vision and mission organizational performance

4. Relationship of vision and mission with image company

5. The relationship between organizational performance and company image 


\section{Methodology}

This research was conducted on 2018 consumer goods company that won the Indonesia Most Admired Companies Award, namely: PT Garuda Food Putra Putri Jaya, PT Gudang Garam, PT Indofood Sukses Makmur and PT Unilever Indonesia.

The research designs used is correlation, which is research that aims to explain a relationship, estimate, test based on existing theories. The correlative relationship refers to the tendency that variations in a variable are followed by variations in other variables.

Organizational performance in this study is only from the aspect of financial perspective, the calculation used uses scoring.

To find out the percentage of value weights financial ratios can use references in accordance with the standard provisions namely:

1. Likwidity ratio (Current Ratio, Quick Ratio)

2. Activity Ratio (Inventory Turn Over, Total Assets Turn Over, Fixed Assets Turn Over)

3. Profitability Ratio (Gross Profit Margin, Operating Profit Margin, Net Profit Margin, Return On Invesment, Return On Equity)

4. Leverage Ratio (Debt Ratio, Debt to Equity Ratio

To find out the relationship of vision and mission statement with performance, so on with corporate image used Spearman Rank Correlation.

\section{Results}

Table 1. Weighted Values of Vision and Mission

\begin{tabular}{|c|c|c|c|c|c|c|c|c|c|c|}
\hline \multirow{2}{*}{ No } & \multirow{2}{*}{$\begin{array}{l}\text { Vision Mission } \\
\text { Component }\end{array}$} & \multirow{2}{*}{ Weight } & \multicolumn{2}{|c|}{ PT GFPPJ } & \multicolumn{2}{|c|}{ PT GG } & \multicolumn{2}{|c|}{ PT ISM } & \multicolumn{2}{|c|}{ PT UI } \\
\hline & & & Score & Value & Score & Value & Score & Nilai & Score & Value \\
\hline 1 & Succinct & 0.10 & 6 & 0.60 & 6 & 0.60 & 6 & 0.60 & 6 & 0.60 \\
\hline 2 & Appealing & 0.10 & 5 & 0.50 & 6 & 0.60 & 6 & 0.60 & 6 & 0.60 \\
\hline 3 & Feasible & 0.10 & 5 & 0.50 & 5 & 0.50 & 5 & 0.50 & 5 & 0.50 \\
\hline 4 & Meaningful & 0.10 & 6 & 0.60 & 6 & 0.60 & 6 & 0.60 & 6 & 0.60 \\
\hline 5 & Measurable & 0.05 & 5 & 0.25 & 5 & 0.25 & 5 & 0.25 & 5 & 0.25 \\
\hline 1 & Customer & 0.05 & 6 & 0.30 & 5 & 0.25 & 6 & 0.30 & 6 & 0.30 \\
\hline 2 & Product And Service & 0.05 & 7 & 0.35 & 6 & 0.30 & 6 & 0.30 & 7 & 0,35 \\
\hline 3 & Market & 0.05 & 6 & 0.30 & 6 & 0.30 & 4 & 0.20 & 6 & 0.30 \\
\hline 4 & Technology & 0.05 & 6 & 0.30 & 5 & 0.25 & 4 & 0.20 & 6 & 0.30 \\
\hline 5 & $\begin{array}{l}\text { Concern For Survival, } \\
\text { Growth and Profitability }\end{array}$ & 0.10 & 7 & 0.70 & 6 & 0.60 & 6 & 0.60 & 7 & 0.70 \\
\hline 6 & Philosophy & 0.05 & 6 & 0.30 & 6 & 0,30 & 6 & 0.30 & 7 & 0.35 \\
\hline 7 & Self Consept & 0.05 & 6 & 0.30 & 5 & 0.25 & 6 & 0.30 & 6 & 0.30 \\
\hline 8 & $\begin{array}{l}\text { Concern For Public } \\
\text { Image }\end{array}$ & 0.10 & 6 & 0.60 & 5 & 0.50 & 6 & 0.60 & 6 & 0.60 \\
\hline 9 & $\begin{array}{c}\text { Concern For Employees } \\
\text { TOTAL }\end{array}$ & $\begin{array}{l}0.05 \\
1.00\end{array}$ & 6 & $\begin{array}{l}0.30 \\
5.90\end{array}$ & 5 & $\begin{array}{l}0.25 \\
5.65\end{array}$ & 6 & $\begin{array}{l}0.30 \\
5.85\end{array}$ & 7 & $\begin{array}{l}0.35 \\
6.00\end{array}$ \\
\hline
\end{tabular}

Table 2. Evaluation by Weighted Value

\begin{tabular}{cccc}
\hline No & Name of Company & Weighted Value & Evaluation \\
\hline 1 & PT GFPPJ & 5.90 & Above average \\
2 & PT GG & 5.65 & Above average \\
3 & PT ISM & 5.85 & Above average \\
4 & PT UI & 6.00 & Above average \\
\hline
\end{tabular}

Table 3. Total Weighted Value of Vision Mission, Organizational Performance Score and Corporate Image Index (CII) 


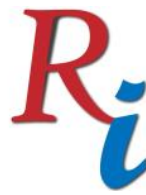

Asia Proceedings of Social Sciences

(APSS)

www.readersinsight.net/APSS

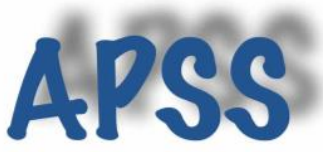

\begin{tabular}{|c|c|c|c|c|c|}
\hline \multicolumn{2}{|c|}{$\begin{array}{c}\text { PT GFPPJ } \\
\text { PT GG } \\
\text { PT ISM } \\
\text { PT UI } \\
\end{array}$} & $\begin{array}{c}5.90 \\
5.65 \\
5.85 \\
6.0 \\
\end{array}$ & & $\begin{array}{c}62.5 \\
58 \\
63.5 \\
62 \\
\end{array}$ & $\begin{array}{l}1.485 \\
1.353 \\
0.873 \\
0.870 \\
\end{array}$ \\
\hline \multicolumn{6}{|c|}{ Table 4. Correlations } \\
\hline \multicolumn{6}{|c|}{ Correlations } \\
\hline & & & $\begin{array}{l}\text { Vision and } \\
\text { Mission }\end{array}$ & $\begin{array}{l}\text { Organization } \\
\text { Performance }\end{array}$ & $\begin{array}{l}\text { Corporate } \\
\text { Image }\end{array}$ \\
\hline \multirow{7}{*}{$\begin{array}{l}\text { Kendall's } \\
\text { tau_b }\end{array}$} & \multirow{2}{*}{$\begin{array}{l}\text { Vision and } \\
\text { Mission }\end{array}$} & Correlation Coefficient & 1.000 & .400 & .400 \\
\hline & & Sig. (2-tailed) & & .327 & .327 \\
\hline & \multirow{3}{*}{$\begin{array}{l}\text { Organization } \\
\text { Performance }\end{array}$} & Correlation Coefficient & .400 & 1.000 & .600 \\
\hline & & Sig. (2-tailed) & .327 & & .142 \\
\hline & & $\mathrm{N}$ & 5 & 5 & 5 \\
\hline & \multirow{2}{*}{$\begin{array}{l}\text { Corporate } \\
\text { Image }\end{array}$} & Correlation Coefficient & .400 & .600 & 1.000 \\
\hline & & $\begin{array}{c}\text { Sig. (2-tailed) } \\
N\end{array}$ & $\begin{array}{c}.327 \\
5\end{array}$ & $\begin{array}{c}.142 \\
5\end{array}$ & 5 \\
\hline \multirow{9}{*}{$\begin{array}{l}\text { Spearman's } \\
\text { rho }\end{array}$} & \multirow{3}{*}{$\begin{array}{l}\text { Vision and } \\
\text { Mission }\end{array}$} & Correlation Coefficient & 1.000 & .600 & .600 \\
\hline & & Sig. (2-tailed) & & .285 & .285 \\
\hline & & $\mathrm{N}$ & 5 & 5 & 5 \\
\hline & \multirow{3}{*}{$\begin{array}{l}\text { Organization } \\
\text { Performance }\end{array}$} & Correlation Coefficient & .600 & 1.000 & .800 \\
\hline & & Sig. (2-tailed) & .285 & & .104 \\
\hline & & $\mathrm{N}$ & 5 & 5 & 5 \\
\hline & \multirow{3}{*}{$\begin{array}{l}\text { Corporate } \\
\text { Image }\end{array}$} & Correlation Coefficient & .600 & .800 & 1.000 \\
\hline & & Sig. (2-tailed) & .285 & .104 & \\
\hline & & $\mathrm{N}$ & 5 & 5 & 5 \\
\hline
\end{tabular}

\section{Findings}

The consumer goods company has a Weighted Value Score $\geq 4$. It means that the company are above-average in fulfilling the components of a good vision and mission.

Based on the results of the Spearman correlation analysis it is known that there is a strong enough positive correlation between vision and mission with organizational performance. It is known that there is a strong enough positive correlation between the vision mission and corporate image. It is known that there is a strong positive correlation between organizational performance and corporate image.However, correlation is not significant enough to describe the relationship between vision and mission with organizational performance.

\section{References}

Bart, C. K. (2007). A comparative analysis of mission statement content in secular and faith-based hospitals. Journal of Intellectual Capital, Vol 8, 682-694.

Bart, C. K., \& Tabone, J.C.(2007). Mission statement rationales and organizational alignment in the not-for-profit health care sector. Health Care Management Review, 23 (4), 54-69.

Campbell, A., \& Yeung, S. (2007). Creating a sense of mission. Long Range Planning, 24(4), 10-20.

David, Fred (2009). Manajemen Strategis, Konsep, Salemba Empat, Jakarta.

William Phanuel, Kofi Darbi (2012). Special Issue - Of Mission and Vision Statements and Their Potential Impact on Employee Behaviour and Attitudes: The Case of A Public But ProfitOriented Tertiary Institution, Ghana Institute of Management and Public Administration Business School, Achimota Accra, Ghana. International Journal of Business and Social Science Vol.3 No. 14 